Florida State University College of Law

Scholarship Repository

Scholarly Publications

10-2006

\title{
Victim Impact Evidence in Federal Capital Trials
}

Wayne A. Logan

Florida State University College of Law

Follow this and additional works at: https://ir.law.fsu.edu/articles

Part of the Criminal Law Commons

\section{Recommended Citation}

Wayne A. Logan, Victim Impact Evidence in Federal Capital Trials, 19 FED. SENT. REP. 5 (2006),

Available at: https://ir.law.fsu.edu/articles/184

This Article is brought to you for free and open access by Scholarship Repository. It has been accepted for inclusion in Scholarly Publications by an authorized administrator of Scholarship Repository. For more information, please contact efarrell@law.fsu.edu. 
Victim Impact Evidence in Federal Capital Trials

Author(s): Wayne A. Logan

Source: Federal Sentencing Reporter, Vol. 19, No. 1, Victims and Sentencing I: Victim Impact

Evidence, the Crime Victims' Rights Act and Kenna (October 2006), pp. 05-12

Published by: University of California Press on behalf of the Vera Institute of Justice

Stable URL: http://www.jstor.org/stable/10.1525/fsr.2006.19.1.05

Accessed: 09/02/2015 15:22

Your use of the JSTOR archive indicates your acceptance of the Terms \& Conditions of Use, available at http://www.jstor.org/page/info/about/policies/terms.jsp

JSTOR is a not-for-profit service that helps scholars, researchers, and students discover, use, and build upon a wide range of content in a trusted digital archive. We use information technology and tools to increase productivity and facilitate new forms of scholarship. For more information about JSTOR, please contact support@ jstor.org. 


\section{Victim Impact Evidence in Federal Capital Trials}

Fifteen years ago, in Payne v. Tennessee, ${ }^{\mathrm{I}}$ the Supreme Court lifted its prohibition on the admission of victim impact evidence (VIE) in the penalty phase of capital trials. According to the Court, admitting evidence on the personal traits of individual murder victims and the toll associated with their killings at once properly allowed the government to show the "uniqueness" of victims, thus counterbalancing defendants' largely unfettered right to adduce mitigation evidence, and permitted the sentencing authority to understand the "specific harm" caused by the murder. ${ }^{2}$

In the wake of Payne, Congress authorized use of VIE as a nonstatutory aggravating factor, and VIE has become a staple in federal death penalty trials, 3 including those of Timothy McVeigh and Zacarias Moussaoui. Despite this prominence, to date no study has been undertaken of VIE in federal capital trials in particular. In this article, I do so, analyzing all federal decisions in the Westlaw database containing victim impact-related claims rendered since Payne, as well as the statutory and case law concerning admission of VIE.

\section{Payne and the FDPA}

In Payne v. Tennessee, the Supreme Court reversed its prior holdings of only a few years before in Booth v. Maryland 4 and South Carolina v. Gathers 5 and concluded that the Eighth Amendment posed no per se bar to the admission of VIE in capital trials. In the penalty phase of Payne's death penalty prosecution for the killings of Charisse Christopher and her two-year-old daughter Lacie Jo, the prosecution adduced testimony of Ms. Christopher's mother, who related how her grandson Nicholas, who himself had been stabbed and witnessed the gruesome events, had been emotionally affected by the killings. ${ }^{6}$ In addition, in his closing arguments to the jury the prosecutor elaborated on the grandmother's testimony, offering that

[n]o one will ever know about Lacie Jo because she never had the chance to grow up.... [Nicholas's] mother will never kiss him goodnight or pat him as he goes off to bed, or hold him and sing a lullaby. [Petitioner's attorney] wants you to think about ... people who love the defendant and things about him. He doesn't want you to think about the people who loved
Charisse Christopher... The people who loved little Lacie Jo ... The brother who mourns for her every single day and wants to know where his best little playmate is. He doesn't have anybody to watch cartoons with him, a little one. These are the things that ... that child will carry forever.?

In a 6-3 decision, the Court rejected Payne's contention that the VIE admitted in his trial violated the Eighth Amendment. Writing for the majority, Chief Justice Rehnquist first disputed the premise of Booth and Gathers that "evidence relating to a particular victim or to the harm that a capital defendant causes a victim's family" is immaterial to capital sentencing outcomes. ${ }^{8}$ Rather, harm traditionally has served as a factor in assessing blameworthiness in punishment decisions; although "this particular evidence-designed to portray for the sentencing authority the actual harm caused by a particular crime-is of recent origin, this fact hardly renders it unconstitutional." 9 According to the Chief Justice, "[v]ictim impact evidence is simply another form or method of informing the sentencing authority about the specific harm caused by the crime in question, evidence of a general type long considered by sentencing authorities." I0

Second, precluding VIE "unfairly weighted the scales in a capital trial," "II insofar as it "deprive[d] the State of the full moral force of its evidence and may prevent the jury from having before it all the information necessary to determine the proper punishment for a first-degree murder." ${ }^{\text {I2 }}$ In order to "keep the balance true'” in capital trials, ${ }^{13}$ the government cannot be constitutionally barred from offering a "'quick glimpse of the life' which a defendant 'chose to extinguish"' ${ }^{24}$ and demonstrating the loss associated therewith. ${ }^{15}$

In rescinding its categorical prohibition, the Court imposed a case-by-case, due process-based admissibility standard requiring that VIE be barred only when it "is so unduly prejudicial that it renders the trial fundamentally unfair." ${ }^{16}$ Furthermore, the Court left intact its holding in Booth that "a victim's family members' characterizations and opinions about the crime, the defendant, and the appropriate sentence" are still barred by the Eighth Amendment. ${ }^{17}$

Federal Sentencing Reporter, Vol. I9, No. I, pp. 5-12, ISSN 1053-9867 electronic ISSN 1533-8363 (C) 2006 Vera Institute of Justice. All rights reserved. Please direct requests for permission to photocopy or reproduce article content through the University of California Press's Rights and Permissions website, http://www.ucpressjournals.com/reprintInfo.asp. DOI: fsr.2006.I9.I.5.

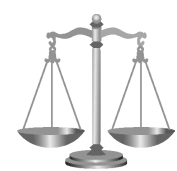

WAYNE A. LOGAN

Visiting Professor of Law, College of William and Mary School of Law (fall 2006); William Mitchell Research Professor of Law, William Mitchell College of Law 
Even though Payne refrained from affirmatively endorsing use of $\mathrm{VIE},{ }^{18}$ the typically highly emotional form of evidence has proved enormously popular. ${ }^{19}$ As part of its expansion of death-eligible crimes in the Federal Death Penalty Act of I994, ${ }^{20}$ Congress expressly approved of VIE in capital trials. ${ }^{21}$ Section 3593(a) of the FDPA provides that aggravating evidence "may include factors concerning the effect of the offense on the victim and the victim's family," ${ }^{22}$ adding that such evidence may include "oral testimony, a victim impact statement that identifies the victim of the offense and the extent and scope of the injury and loss suffered by the victim and the victim's family, and any other relevant information." ${ }^{23}$

In the event the sentencing authority unanimously finds that the government has established beyond a reasonable doubt the existence of at least one statutory aggravating factor, ${ }^{24} \mathrm{VIE}$, a nonstatutory aggravator, ${ }^{25} \mathrm{can}$ be considered in capital decisions, presuming adequate prior notice of intent to admit VIE is provided. ${ }^{26}$ Unlike their state court counterparts, ${ }^{27}$ federal courts with some frequency have required rather detailed notice of VIE that the government proposes to use. ${ }^{28}$ In granting a defense motion to amend a death notice, for instance, the Northern District of Indiana held that the government must indicate "who will offer victim impact evidence, the relation the witness is to the victim, the form of testimony (i.e., written or oral statement) and a summary of the anticipated testimony." ${ }^{29}$ At the same time, however, federal courts have refrained from requiring that the actual VIE of witnesses be submitted in written form for the court's preliminary review and have refused to restrict VIE ultimately presented by witnesses to such testimony. ${ }^{30}$

Federal trial courts have at times also evinced concern over the unique nature of VIE and adopted special procedures. In particular, citing concern over the anticipated prejudicial nature of VIE, three federal courts have required a bifurcated sentencing proceeding in which VIE is to be heard only after the jury determines the threshold mens rea and statutory aggravating factor requirements..$^{3}$

\section{VIE in the Federal System}

Payne and the FDPA plainly allow for the consideration of VIE in the sentencing phase of capital trials, yet they provide only the most generalized guidance on its admissibility and use. For its part, the FDPA, while not governed by the Federal Rules of Evidence, ${ }^{32}$ requires that trial courts ensure that the probative value of evidence (including VIE) is not outweighed by the danger of undue prejudice. 33 The sole constitutional limit prescribed by Payne, sounding in due process, is that any VIE admitted not be "so unduly prejudicial that it renders the trial fundamentally unfair." 34 In imposing the case-by-case analytic framework in lieu of Booth's Eighth Amendment per se bar against VIE, Payne (the concurring opinions of Justices Souter and O'Connor in particular ${ }^{35}$ expressed faith that trial and appellate courts would vigorously police admission of VIE.
This expectation, however, has not translated into successful challenges to VIE. Despite qualifying as what Judge Richard Matsch, presiding judge in the Timothy McVeigh capital trial, called "the most problematical of all the aggravating factors [which] may present the greatest difficulty in determining the nature and scope of the information to be presented," ${ }^{6}$ VIE has proved notably resistant to successful challenge. During the fifteen years since Payne, while trial courts have at times acceded to defense requests to regulate the procedures pertaining to the admission of VIE, 37 and on occasion more substantive matters, ${ }^{3}$ not a single appellate court has overturned a death verdict as a result of impermissible VIE. 39

Federal appellate courts either reject claims outright or, employing Payne's due process standard, find that that the VIE was not "so unduly prejudicial that it render[ed] the trial fundamentally unfair." ${ }^{\circ}$ In applying the open-ended test, courts often resort to a highly relativistic inquiry, weighing the VIE against the heinousness of the crime ${ }^{4}$ or the relative amount of trial time dedicated to the VIE, with many courts actually counting the number of transcript pages compared to other aggravating as well as mitigating evidence. $4^{2}$ The Fourth Circuit, for instance, while noting that the VIE presented had "substantial impact," and even conceding arguendo that it exceeded the "quick glimpse" authorized by Payne, concluded in United States $v$. Barnette that in relative terms the VIE did not "contaminate" the sentencing proceeding as a whole. 43 Meanwhile, in the subsequent decision United States $v$. Stitt, 44 another Fourth Circuit panel used the same approach in what it denominated as harmless error analysis to condone the government's violation of the statutory notice requirement. 45

The following provides an overview of the substantive shape, form, and extent of VIE used today in federal capital trials.

\section{A. Background and Number of VIE Witnesses}

The FDPA fails to provide limiting criteria on either the identity or the number of persons qualified to testify, freeing federal courts to liberally admit VIE. This expansiveness was most apparent in the trials of Timothy McVeigh and Zacarias Moussaoui. In McVeigh, the government presented thirty-eight VIE witnesses, including twenty-six survivors of deceased victims, three persons injured, one employee of the day care center in the bombed Murrah Federal Building, and eight rescue and medical workers. ${ }^{4}$ While noting that the witnesses were "significant in number," the Tenth Circuit lauded the government's "self-restraint" 47 and observed that the volume "comprised an extremely small percentage of the number of potential witnesses the government might have called to testify about the $\mathrm{I} 68$ victims who died in the blast and the impact of the explosion on the numerous injured victims." ${ }^{8}$ According to the Tenth Circuit, "[t]he sheer number of actual victims and the horrific things done to them necessarily allows for the introduction of a greater 
amount of victim impact testimony in order for the government to show the 'harm' caused by the crime." 49

Similarly, in the sentencing phase of the Moussaoui trial, the government put on over three dozen VIE witnesses, including family and friends, police and firefighters, and ex-mayor Rudolph Giuliani (the government's first VIE witness)..$^{\circ}$ Given that Moussaoui's predicate offense involved the deaths of almost three thousand individuals and injuries to countless more, what might be called the "McVeigh metric" will very likely be successfully invoked in any subsequent appeal. Payne's authorized "quick glimpse of the life [the defendant] chose to extinguish," ${ }^{\mathrm{I}}$ it is fair to say, quite clearly assumes modified meaning in the context of mass killings, which, if future acts of terrorism come to pass, the federal courts will be obliged to elucidate. ${ }^{2}$

Federal courts, however, have been inclined to generously admit VIE in more traditional capital trials, permitting testimony from not just family members, as provided for in the FDPA, 53 but also teachers, neighbors, school classmates, friends, and coworkers. ${ }^{54}$ In United States $v$. Allen, 55 for instance, a capital trial involving the death of a security guard during a failed armed bank robbery, the government offered eleven VIE witnesses, including a former coworker, two bank employees, and the victim's ex-wife. ${ }^{6}$ Meanwhile, in United States v. Barnette, 57 which involved a prosecution for a double murder, the government called seven VIE witnesses. Highlighting further still the mercurial nature of the issue, a federal court in Massachusetts without elaboration held that the government could present three or four family members for each victim in a charged double murder..$^{8}$

In sum, federal courts evince a distinct reluctance to limit the number of VIE witnesses and the persons eligible to provide such information. ${ }^{59}$ While the Tennessee jury in Payne itself heard from only the grandmother/mother of the two victims (with her testimony echoed by the state prosecutor), federal capital trials today can involve considerably greater numbers of witnesses, without any necessity of sanguinary connection. ${ }^{60}$

\section{B. What Qualifies as "Impact"}

Likewise, the definitional scope of "impact" has been noticeably indefinite, with the FDPA again providing only modest help. By its terms, the FDPA permits VIE that informs the sentencing authority of "the effect of the offense on the victim and the victim's family ... and the extent and the scope of the injury and loss suffered by the victim and the victim's family, and any other relevant information." ${ }^{\text {II }}$ Federal courts, however, have permitted evidence well beyond the "loss suffered by the victim and the victim's family," ${ }^{2}$ presumably (yet never expressly) relying upon the catchall FDPA language "and any other relevant information." ${ }_{3}$ In Moussaoui, for instance, the government successfully mounted extensive testimony on the impact on not just family but also friends, coworkers, rescue personnel, and even New York City's then mayor, ${ }^{64}$ as well as the disruptive impact on New York City ${ }^{65}$ and the Pentagon. ${ }^{66}$ In McVeigh, jurors over the course of two days' testimony heard extensive testimony from family and friends, ${ }^{67}$ as well as gripping evidence on the emotional harms suffered by professional emergency rescue workers and police. ${ }^{68}$

Courts have also been amenable to what might be called "institutional" VIE. For instance, in United States $v$. Battle, ${ }^{69}$ the government successfully mounted testimony from three prison guards who testified of the impact the killing of a fellow guard had on the climate of a federal prison. In upholding its admission, the Eleventh Circuit deemed the testimony proper because it

told the jury that the harm caused by Battle's killing of Officer Washington was not simply to take a life, but also to embolden other prisoners, to increase the harassment of guards by prisoners, and to increase the stresses on prison staff (making them feel less safe) in the peculiar environment of a prison in which many inmates are already serving life sentences or long sentences. ${ }^{70}$

More recently, a federal district court in Kansas tacitly approved of VIE relating to the impact of the murder of a local sheriff on the county sheriff's department and the people of the county, requiring only that the government provide additional detail in its notice relative to the pro-

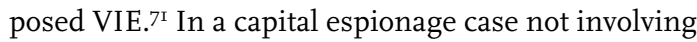
deaths, the Eastern District of Virginia rejected a vagueness challenge to VIE associated with "[t]hreats to national security. ${ }^{2}$ According to the court, such threats "are not obtuse principles, and the potential victims are clear." 73

By the same token, federal courts have been disinclined to admit VIE concerning victims of any crimes other than those for which the defendant is being sentenced. 74 In United States v. Sampson, 75 the District of Massachusetts expressed concern over the fact that the FDPA fails to expressly mention such evidence, addressing only VIE on the charged "offense," and that, even if it did, the additional VIE would "create too great a risk that the jury would be influenced by sympathy and passion" in violation of due process. ${ }^{76}$

Also, in one of the handful of instances in the study period in which a trial court found fault with VIE, the Southern District of New York, in addressing pretrial motions in the capital prosecution of two individuals for the bombing of U.S. embassies in Kenya and Tanzania, curbed government efforts to bifurcate VIE into fatal and nonfatal outcomes.77 While otherwise deeming the aggravating factors "grave risk of death to additional persons," "multiple killings or attempted killings," and VIE as distinct and nonduplicative, the court found that the proposed aggravator of "serious injury to surviving victims" was "entirely and wholly subsumed" by the VIE aggravator..$^{7}$ While both "function[ed] to provide the jury with details concerning the widespread human trauma" of 
the bombings, as authorized by Payne,79 the government's strategy amounted to an impermissible "attempt to spin off" aggravators from what "should really only be one."8० In requiring that the two aggravators be consolidated, the court added that

what is most problematic is the fact that, because such parsing of categories serves no evidentiary purpose (since such evidence would still be admitted under the aegis of the umbrella aggravator), the sole motivation for doing so is to ratchet up the number of aggravating factors and "give the government free rein to trump whatever mitigating factors are raised by the defendant." ${ }^{\text {r }}$

\section{Victim Traits}

Relying upon the FDPA's general allowance for information "that identifies the victim of the offense," federal courts generously admit VIE relating to the personal traits of victims. In Jones $v$. United States, ${ }^{82}$ the Supreme Court rejected a claim that victim trait-related VIE was duplicative of "victim vulnerability," another nonstatutory aggravating factor noticed by the government. According to the five-member Jones majority, victim vulnerability and traits are distinct, with the latter serving to inform the jury of the "victim's individual uniqueness." ${ }_{3}$ According to the Court, while the "concepts of victim impact and victim vulnerability may well be relevant in every murder case, evidence of victim vulnerability and victim impact in a particular case are inherently individualized." ${ }^{4}$ Similarly, Jones rebuffed challenges to VIE sounding in vagueness and overbreadth, ${ }^{85}$ as have other courts. ${ }^{86}$

While federal case law lacks the hugely varied instances of positive victim traits evidenced in state opinions, ${ }^{87}$ and "comparative worth" assessments are checked by the FDPA's requirement that jurors certify that the backgrounds of victim and defendant did not influence their capital decision, ${ }^{88}$ federal courts are nonetheless predisposed to freely admit victim trait evidence. In United States v. Hall, for instance, the Fifth Circuit condoned admission of VIE to the effect that the victim was an aspiring doctor. ${ }^{89}$ In United States v. Fulks, 90 the Fourth Circuit upheld admission of a letter sent by an adult murder victim to her sister, referring to her determination to recover emotionally from childhood sexual abuse by her father and to leave an abusive spouse. ${ }^{9 \mathrm{I}}$ Meanwhile, in United States v. Bernard, $9^{2}$ the Fifth Circuit, citing Justice Souter's concurring opinion in Payne approving of "contextual evidence" relating to victims, ${ }^{93}$ upheld admission of evidence that the victims were "youth ministers" who were attending a revival meeting on the day they were killed. ${ }^{4}$ Because religion figured centrally in the victims' lives, the Bernard court held, "it would be impossible to describe their 'uniqueness as individual human beings' without reference to their faith." 95

\section{Opinion Evidence}

Finally, federal courts have been vigilant in enforcing Booth's remaining prohibition of (I) witness characteriza- tions of capital defendants and their crimes and (2) witness opinions of whether death should be imposed..$^{6} \mathrm{In}$ contrast to the states, where the bans have shown signs of erosion, 97 federal government efforts to admit such testimony has come in for critical scrutiny. In United States $v$. Barnard, ${ }^{9}$ for instance, the jury received written statements from the mother and father of the victim that provided as follows:

(Mother): "I'm sorry for you, for your heart to be so hard, you couldn't even see the innocence of the two you've killed."

(Father): "I truly believe that ... our children were tragically and recklessly stolen from us. There was no profit to be gained, no angry exchange, it was just a useless act of violence and total disregard of life." 99

The Fifth Circuit deemed the statements impermissible (yet harmless) witness characterization testimony. ${ }^{100}$

While no decisions in the study involved a challenge to prosecution witness sentence opinions, one rejected an effort by the defense to avail itself of anti-death sentiments

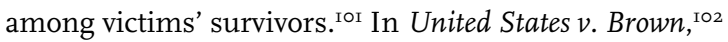
the Eleventh Circuit denied a claim that the government violated Bradyv. Maryland by failing to disclose that a victim's spouse opposed the death penalty, given that Booth proscribed admission of such testimony. ${ }^{103}$

Despite the continued existence of the sentence opinion bar, the Moussaoui trial perhaps signals coming use of an alternate form of testimony that subtly communicates opinion testimony - on behalf of the defense. Since Payne, it has not been uncommon for state courts to uphold admission of testimony from prosecution witnesses containing thinly veiled pro-death opinions. In one Nevada capital case, for instance, a surviving spouse urged the jury to "show no mercy," which the Nevada Supreme Court unanimously concluded did not qualify as opinion but rather amounted to a request that the jury return the most serious sentence it felt appropriate. ${ }^{104}$ Similarly, the Illinois Supreme Court upheld admission of the following statement offered by the wife of a murdered police officer:

My family and I are very confident that all of you will return a quick verdict which will send a message to my children, society, and the law enforcement community that we simply will not tolerate or accept our last means of protection being annihilated on our streets. Renew our faith in the criminal justice system and bring a phase of closure to this ongoing nightmare that fills our lives. ${ }^{\text {IO5 }}$

In Moussaoui, the defense sought to turn this ambiguity to its own advantage by calling twenty-four survivors of the 9/II tragedy. ${ }^{\text {Io6 }}$ Although not allowed to specify whether they favored death or not, the witnesses spoke of their recovery since 9/II, used terms such as "compassion" and "respect for life," ${ }^{107}$ and testified with limited 
emotion (as compared to the government's VIE witnesses). ${ }^{108}$ One survivor, whose son died in the World Trade Center, calmly spoke of how he had tried to channel the "mixture of rage, murderous rage, and also deep feelings of sadness" he felt. "I had a choice of staying with these feelings or sort of nurturing them. I tried to think of ways that I could learn more. I felt the need for bridges of understanding with people who could do this kind of thing." ${ }^{\circ}$ Another survivor, who lost his father in the World Trade Center attacks, offered that "I saw that if I had let myself succumb to the fear and anger and vengeance, then more than the planes would have been hijacked that day." "II

It remains to be seen whether other federal courts will be similarly receptive to such testimony ${ }^{\mathrm{III}}$ or, like state courts, will reject defense efforts to avail themselves of survivor VIE testimony. ${ }^{\mathrm{II} 2}$ Either way, it is likely that federal (and state) courts increasingly will be pressed to elucidate the bounds of permissible "opinion" VIE. ${ }^{\text {II3 }}$

\section{Conclusion}

As the foregoing makes clear, today federal courts admit VIE of a quality and degree far in excess of Payne's envisaged "quick glimpse of the life defendant[s] chose to extinguish." II4 This tendency is most vividly apparent in capital prosecutions for mass killings, such as McVeigh and Moussaoui, the tragic scope of which naturally presses the bounds of both "victim" and "impact." Yet, as shown above, with the meager limits imposed by the FDPA and Payne as a backdrop, federal courts also liberally admit VIE in more typical capital cases. And, despite notice requirements and increasing use of preliminary judicial review, the emotionally potent evidence is merely thrown into the decisional mix for capital jurors, ${ }^{\mathrm{II} 5}$ without benefit of a pattern jury instruction in any circuit, ${ }^{\mathrm{II} 6}$ with the sole constitutional caveat being that the VIE not be so unduly prejudicial "that it render[s] the trial fundamentally unfair."II7

In turn, as this study of the case law over the fifteen years since Payne shows, trial and appellate courts have been disinclined to find fault with VIE. While in a number of instances trial courts reined in government efforts to use VIE, almost always finding fault with procedural aspects such as notice, to date no federal appellate court has deemed admitted VIE to be reversible error. It is now apparent, as Payne would have it, that VIE is "simply another form or method of informing the sentencing authority" in federal capital trials. ${ }^{\mathrm{I}}{ }^{18}$ Just as death is no longer seen as quite so "different" a penalty than once purported for juristic purposes, ${ }^{\text {II9 }}$ neither is VIE, leading to a symmetric use of the emotionally potent form of evidence in capital and noncapital trials alike. ${ }^{\mathrm{I} O}$ What this means for future capital trials in the federal system remains to be seen.

\footnotetext{
Notes

1501 U.S. 808 (1991).

2 Id. at 821,826 .
}

3 See United States v. Sampson, 332 F. Supp. 2d 325, 338 (D. Mass. 2004) (noting that victim impact evidence has become a "regular, legitimate feature" of federal capital trials).

4482 U.S. 496 (1987)

5490 U.S. 805 (1989).

6 Payne, 501 U.S. at 814-15.

7 ld. at 816.

8 Id. at 819.

9 Id. at 821.

10 ld. at 825 .

11 Id. at 809.

12 ld. at 825 .

13 Id. at 827 (quoting Snyder v. Massachusetts, 291 U.S. 97, 122 (1934)).

14 Id. at 822 (quoting Mills v. Maryland, 486 U.S. 367, 397 (1988) (Rehnquist, C.J., dissenting).

15 ld. at 830 .

16 Id. at 825.

17 Id. at 830 n.2.

18 Id. at 827 ("We thus hold that if the State chooses to permit the admission of victim evidence . . . the Eighth Amendment erects no per se bar."); id. at 831 (O'Connor, J., concurring) ("We do not hold today that victim impact evidence must be admitted, or even that it should be admitted.").

19 See supra note 3 and accompanying text. In addition to being a mainstay of federal capital trials, VIE is permitted in thirty. five of the thirty-eight capital states and the military. Kenji Yoshino, The City and the Poet, 114 YALE L.J. 1835, 1869 (2005). For additional discussion of the popularity of VIE, as well as the reasons inspiring its rapid proliferation, see Wayne A. Logan, Through the Past Darkly: A Survey of the Uses and Abuses of Victim Impact Evidence in Capital Trials, 41 ARIz. L. REv. 143 (1999) [hereinafter Logan, Past Darkly].

20 Federal Death Penalty Act of 1994, Pub. L. No. 103-322, 108 Stat. 1796,1959 (codified in scattered sections of 18 U.S.C.).

21 See United States v. McVeigh, 944 F. Supp. 1478, 1491 (D. Colo. 1996) (recognizing that $\S 3593(a)$ "specifically contem. plates the use of victim impact evidence as an aggravating factor").

2218 U.S.C. § 3593(a).

23 ld.

24 See 18 U.S.C. § 3593(a), (e).

25 See United States v. Davis, 912 F. Supp. 938, 947 (E.D. La. 1996) (characterizing VIE as a nonstatutory aggravator in federal capital proceedings).

26 Such notice is required unless the government's evidence is "used merely to rebut mitigating evidence offered by the defendant." United States v. Sampson, 335 F. Supp. 2d 166, 186.87 (D. Mass. 2004).

27 See Logan, Past Darkly, supra note 19, at 151-52.

28 See United States v. Taylor, 316 F. Supp. 2d 730, 743 (N.D. Ind. 2004); United States v. O'Driscoll, 203 F. Supp. 2d 334, 340.41 (M.D. Pa. 2002); United States v. Cooper, 91 F. Supp. 2d 90, 111 (U.S.D.C. 2000); United States v. Glover, 43 F. Supp. 2d 1217, 1234-36 (D. Kan. 1999). See also United States v. Rodriguez, No. 2:04-CR-55, 2006 WL 435581 (D.N.D. Feb. 21, 2006) (noting parties' agreement that government will provide defense "with the names of the witnesses and outlines of their testimony"); United States v. Johnson, 136 F. Supp. 2d 553, 561 (W.D. Va. 2001) (requiring government to amend its notice to amplify its initial statement that it was merely to present evidence on the nonstatutory aggravator of "Victim Impact").

29 Taylor, 316 F. Supp. 2d at 743. See also Cooper, 91 F. Supp. $2 \mathrm{~d}$ at 111 (ordering government to amend its notice to include "more specific information concerning the extent and scope of the injuries and loss suffered by each victim, his or 
her family members, and other relevant individuals, and as to each victim's 'personal characteristics'”).

30 See, e.g., United States v. Caro, 433 F. Supp. 2d 726, 730 (E.D. Va. 2006) (rejecting defense motion for pretrial judicial review); United States v. Jordan, 357 F. Supp. 2d 889, 906 (E.D. Va. 2005) (rejecting defense motion, noting that " $[t]$ here is no statutory requirement that the Court conduct such a pre. view"); United States v. Edelin, 134 F. Supp. 2d 59, 79 (D.D.C. 2001) (rejecting preliminary review). But see United States v. Williams, No. S100CR.1008 (NRB), 2004 WL $2980027 * 23$ (S.D.N.Y. 2004) (denying defense motion to compel a written statement describing the testimony of each VIE witness the government intended to call, while preserving opportunity for future "motion to discover" at end of guilt phase).

31 See United States v. Mayhew, 380 F. Supp. 2d 936, 957 (S.D. Ohio 2005); United States v. Johnson, 362 F. Supp. 2d 1043, 1106 (N.D. lowa 2005); United States v. Davis, 912 F. Supp. 938, 949 (E.D. La. 1996).

32 See 18 U.S.C. $\S 3593$ (c) (providing that "[i]nformation is admissible regardless of its admissibility under the rules gov erning admission of evidence at criminal trials.").

33 Id.

34 Payne, 501 U.S. at 825.

35 Id. at 831 (O'Connor, J., concurring); id. at 836 (Souter, J., concurring).

36 United States v. McVeigh, 958 F. Supp. 512, 513 (D. Colo. 1997). See also United States v. Gilbert, 120 F. Supp. 2d 147 149 (D. Mass. 2000) ("Congress has not provided specific guidelines for the admissibility of [VIE]. Rather, it has entrusted trial judges with both substantial responsibility and with broad discretion to act as guardians of the sentencing process.").

37 See supra notes 28-30 and accompanying text.

38 See United States v. Bin Laden, 126 F. Supp. 2d 290, 300.01 (S.D.N.Y. 2001) (requiring that fatal and nonfatal injuries to victims be consolidated into a single umbrella VIE factor); Sampson, 35 F. Supp. 2d at 192.93 (excluding twenty-seven. minute video chronicling the victim's life set to poignant music and VIE relating to murder for which defendant is not being sentenced); United States v. O'Driscoll, No. 4: CR-01. 277, 2003 WL $1401973 * 2$ (M.D. Pa. 2003) (requiring that government redact letter containing survivors' characteriza. tions of defendant and murders, as prohibited by Booth). In addition, although not revealed as part of the study's Westlaw queries, Judge Matsch in the McVeigh trial, while not granting defense requests to undertake a preliminary hearing on proposed VIE, exercised considerable control, barring tes. timony regarding the deaths of nineteen children, the conditions of victims' bodies, funeral arrangements, holiday photos of victims, and a video of a typical day in the Murrah Building credit union (where six victims worked). John Gibeaut, The Last Word: Jury Is Still Out on Impact Evidence, A.B.A. J. 42, 43 (Sept. 1997).

39 The study involved a Westlaw search of all decisions (unpub. lished and published) issued from 1991 through July 2006. To ensure capture of all available data, both the relevant Westlaw key number and "victim impact" queries were used. Because understanding of the use of VIE in federal capital trials in particular was sought, decisions on claims brought by state habeas petitioners were excluded.

40 Payne, 501 U.S. at 825

41 See United States v. Hall, 152 F.3d 381, 405 (5th Cir. 1998) (quoting Payne, 501 U.S. at 832 (O'Connor, J., concurring)) ("We are confident that [the VIE] did not inflame [the jury's] passions more than did the facts of the crime."). To this, Justice Stevens responded in his Payne dissent that

[w] e should not be concerned with the cases in which vic. tim impact evidence will not make a difference. We should be concerned instead with the cases in which it will make a difference. In those cases, defendants will be sentenced arbitrarily to death on the basis of evidence that would not otherwise be admissible because it is irrelevant to the defendant's moral culpability. Id. at 866 (Stevens, J., dissenting)

42 The Eighth and Fourth Circuits have been especially partial to this approach. See United States v. Nelson, 347 F.3d 701, 713.14 (8th Cir. 2003) (condoning VIE because it was provided by only six witnesses and consumed 101 of 1,100 pages of trial transcript and was offset by defense mitigation evidence); Barnette, 211 F.3d at 818 (4th Cir. 2000) (noting that the VIE consumed only 22 percent of the government's case in aggravation and that testimony from defendant's fam. ily consumed 41 percent of the mitigation case).

43 Barnette, 211 F.3d at 818.

44250 F.3d 878 (4th Cir. 2001).

45 Id. at 898-99. For discussion of the risks presented by "quan titative" harmless error analysis relative to VIE in capital trials, see Logan, Past Darkly, supra note 19, at 185.90.

46 United States v. McVeigh, 153 F.3d 1166, 1216 (10th Cir. 1998), cert. denied, 526 U.S. 1007 (1999). For further detail on the VIE witnesses and varieties of impact offered at McVeigh's trial, as surveyed by McVeigh's trial counsel, see Richard Burr, Litigating with Victim Impact Testimony: The Serendipity That Has Come from Payne v. Tennessee, 88 CoRNELL L. REV. 517, 521.25 (2003).

47 McVeigh, 153 F.3d at 1221.

48 Id. at 1216.

49 Id. at 1221.

50 Jerry Markon \& Timothy Dwyer, Horror Takes the Stand at the Moussaoui Trial, WASH. Post, Apr. 7, 2006, at A1.

51 Payne, 501 U.S. at 831.

52 Two other less high-profile federal trials also involved significant numbers of witnesses - the trial of Terry Nichols, for his involvement in the Oklahoma City bombing (fifty-five VIE witnesses), and Mohamed Rashed Daoud Al-Owhali, for his involvement in the 1998 bombing of the U.S. embassy in Nairobi, Kenya, in which 213 individuals were killed (twenty. six VIE witnesses). For discussion of these trials, see Wayne A. Logan, Pathos and Punishment: The Use of Victim Impact Evidence in Mass Killing Prosecutions (manuscript on file with author).

53 See 18 U.S.C. § 3593(a).

54 See, e.g., United States v. Nelson, 347 F.3d 701, 713 (8th Cir. 2003) (teacher, neighbor, and classmate); United States v. Bernard, 299 F.3d 467, 478 (5th Cir. 2002) (friend and former coworker); United States v. Holder, 247 F.3d 741, 779 (8th Cir. 2001) (coworker and former coworker); United States v. Paul, 217 F.3d 989, 995 (8th Cir. 2000) (coworker).

55247 F.3d 741 (8th Cir. 2001).

56 Id. at 779.

57211 F.3d 803 (4th Cir. 2000).

58 United States v. Sampson, 335 F. Supp. 2d 166, 189 (D. Mass. 2004).

59 States have been similarly averse to placing numeric limits on VIE, with only a few imposing a limit. See Commonwealth v. Terry, 153 S.W.3d 794, 805 (Ky. 2005) (limiting prosecutor to one VIE witness); State v. Muhammad, 678 A.2d 164, 180 (N.J. 1996) (limiting prosecution to one VIE witness absent exceptional circumstances). Likewise, only rarely have states seen fit to specify who can provide VIE. See Logan, Past Darkly, supra note 19, at 154 n.63 (citing laws in Delaware, Louisiana, Mississippi, New Jersey, and Oklahoma).

60 This breadth, it bears mention, differs from the narrower approach to defining "victim" in noncapital cases. See, e.g., United States v. Terry, 142 F.3d 702, 710-12 (4th Cir. 1998) (rejecting sentence increase under Guidelines for involuntary 
manslaughter conviction based on "extreme psychological impact" on survivors because there was "no evidence that the families in question had any relationship to the offense beyond their relationship to the direct victims").

6118 U.S.C. § 3593(a).

62 Notably, Payne itself variously refers to the harms caused a "victim's family" and the "loss to the victim's family and to society." Payne, 501 U.S. at 819, 822. See also id. at 835 (Souter, J., concurring) ("information revealing the individuality of the victim and the impact of the crime on the victim's sur. vivors"); id. at 830 (O'Connor, J., concurring) ("impact on the victim's family and community"). More recently, in United States v. Jones, 527 U.S. 373 (1999), the Court characterized VIE as addressing the "emotional impact of the murder on the victim's family" and the "effect of the crime on her family." Id. at 395, 399. See also id. at 401 (noting that "every murder will have an impact on the victim's family and friends").

6318 U.S.C. $\S 3593(a)$. Again, only a handful of states have specified what can be deemed "impact." See Logan, Past Darkly, supra note 19, at 162 n.115 (noting, inter alia, Missis. sippi's law limiting impact to "the financial, emotional and physical effects of the crime on the victim and the victim's family").

64 See supra note 50.

65 The jury found beyond a reasonable doubt that Moussaoui caused "tremendous disruption to the function of the City of New York and its economy," as evidenced by inter alia: the deaths of state and federal employees; the loss of buildings, vehicles, and weapons; disruption of communications and transportation systems; the closure of parks, playgrounds, and schools; the displacement of and economic harm to businesses; property losses costing several billon dollars; and the delay in the meeting of the UN and a special meeting of the UN "called to address UNICEF issues." United States v. Moussaoui, U.S. District Court for the Eastern District of Virginia, No. 01-455.A, Special Verdict Form for Phase II, at 3.5, May 3, 2006

66 The jury found beyond a reasonable doubt that Moussaoui caused "tremendous disruption to the function of the Pentagon," as evidenced by inter alia: destruction of several military centers and the loss of a majority of their respective staffs; the destruction and damage to hundreds of thousands of square feet of office space; the destruction of a part of the Pentagon that had been recently renovated at a cost of $\$ 250$ million; and destruction of equipment specifically designed for the Pentagon "because of its unique role as the center" of U.S. military operations. Id. at 5.

67 McVeigh, 153 F.3d at 1219-20.

68 Scott Robinson, Editorial, Stacking the Deck: Heart-Wrenching "Victim Impact" Statements Make It Virtually Impossible for Jurors to Set Emotions Aside, Rocky MTN. News, June 8, 1997, at $1 \mathrm{~B}$.

69173 F.3d 1343 (11th Cir. 1999).

70 Id. at 1348 n.6. But see United Sates v. Quinones, No. 00 CR.761 (JSR), 2004 WL 1234044 (S.D.N.Y. 2004) (demurring on the question of the admissibility of “'institutional'” VIE, "i.e., the impact that the defendants' alleged crimes had on the New York Police Department").

71 United States v. Cheever, 423 F. Supp. 2d 1181, 1211 (D. Kan. 2006).

72 United States v. Regan, 228 F. Supp. 2d 742, 752 (E.D. Va. 2002).

73 Id.

74 Similarly, states typically permit VIE relative only to the offense(s) being tried. North Carolina, however, represents an exception. See State v. Robinson, 451 S.E.2d 196, 204-05 (N.C. 1994) (permitting VIE from child of a woman the defendant had murdered several years earlier).
75335 F. Supp. 2d 166 (D. Mass. 2004).

76 Id. at 193 (citing 18 U.S.C. § 3593(a)).

77 United States v. Bin Laden, 126 F. Supp. 2d 290, 300 (S.D.N.Y. 2001).

78 ld.

79 ld.

80 ld.

81 Id. (citation omitted).

82527 U.S. 373 (1999).

83 Id. at 399.

84 Id. at 401.

85 Id. at 400-401.

86 See, e.g., United States v. Bourgeois, 423 F.3d 501, 510-11 (5th Cir. 2001). Likewise, in Webster v. United States, 162 F.3d 308, 324 (5th Cir. 1998), the Fifth Circuit rejected the claim that VIE was duplicative of the "especially heinous, cruel, and depraved" statutory aggravating factor.

87 See Logan, Past Darkly, supra note 19, at 157-59.

8818 U.S.C. § 3593(f).

89 United States v. Hall, 152 F. 3d 381, 405 (5th Cir. 1998).

90454 F.3d 410 (4th Cir. 2006).

91 According to the panel, the letter "highlighted struggles [the victim] had faced in her life and the strength with which she confronted them." Id. at 436. At the same time, the victim's history of sexual abuse and determination to avoid further abuse possibly provided jurors with a sense of heightened harm, because the victim "suffered all the more" as a result of the sexual abuse perpetrated by the defendant. $I d$.

92299 F.3d 467 (5th Cir. 2002).

93 Id. at 479 (citing Payne, 501 U.S. at 842 (Souter, J., concurring)).

94 ld.

95 Id. (citation omitted). By the same token, reflecting the stance of state courts, the Eastern District of Virginia rejected an argument that defendants did not deserve death because their murder victims were alleged drug dealers. United States v. Beckford, 962 F. Supp. 804, 822 (E.D. Va. 1997).

96 See Payne, 501 U.S. at 830 n.2.

97 See Wayne A. Logan, Victims, Survivors, and the Decisions to Seek and Impose Death, in Wounds That Do Not BIND: VICTIMBased Perspectives on the Death Penalty 161, 166.68 (James R. Acker \& David R. Karp eds., 2006); Wayne A. Logan, Opining on Death: Witness Sentence Recommendations in Capital Trials, 41 B.C. L. Rev. 517, 528.33 (2000) [hereinafter Logan, Opining on Death].

98299 F.3d 467 (5th Cir. 2002).

99 Id. at 480.

100 ld. at 480.81

101 For discussion of the varied opinions on capital punishment and the reluctance of courts to admit them, either at the charging or sentence decision-making stage, see Wayne A. Logan, Declaring Life at the Crossroads of Death: Victims' AntiDeath Penalty Views and Prosecutors' Charging Decisions, 18 CRim. Just. Ethics 41, 44-45 (1999) [hereinafter Declaring Life]. 102441 F.3d 1330 (11th Cir. 2006).

103 Id. at 1352.

104 Witter v. State, 921 P.2d 886, 895.96 (Nev. 1996).

105 People v. Williams, 692 N.E.2d 1109, 1124 (III. 1998). The Tennessee prosecutor's closing argument in Payne itself, see text accompanying note 7 , provides another example of notso-veiled opinion.

106 Neil A. Lewis \& David Stout, At Sentencing, Moussaoui Is Defiant, N.Y. TIMES, May 4, 2006.

107 Timothy Dwyer \& Jerry Markon, For Victims' Families, Verdict Elicits Mix of Shock, Relief, WASH. Post, May 4, 2006. A similar instance occurred in a Florida capital trial, where a survivor and death penalty opponent was threatened with 
contempt if she expressed her opinion. On the stand, she referred to the defendant as a "gentleman" and signaled her opposition by noting that she worked as a death penalty abolitionist. Tom Jicha, The Risk of Forgiveness: On 48 Hours, Mercy Raises Troubling Questions, Sun SentInel (Ft. Laud. erdale, Fla.), Oct. 2, 1997, at 3E.

108 Jerry Markon \& Timothy Dwyer, Moussaoui Gets Some Unusual Help; Some 911 Relatives Testify for the Defense, WASH. Post, Apr. 20, 2006, at A10.

109 ld.

110 /d.

111 For discussion of this strategy more generally, see Adrienne N. Barnes, Reverse Impact Testimony: A New and Improved Victim Impact Statement, 14 CAP. DEF. J. 245 (2002).

112 Logan, Declaring Life, supra note 101, at 44.

113 See Logan, Opining on Death, supra note 97, at 526.29, 545 47 (discussing the enduring ambiguity over the continued vitality of the sentence opinion testimony bar, complicated by its close resemblance to similar testimony that is admissible, such as prosecutorial opinions on whether death is warranted and defense "pleas for mercy").

114 Payne, 501 U.S. at 822.

115 Highlighting this, in the government's closing argument in the Moussaoui case prosecutor David Raskin urged that jurors mark the VIE block on their verdict form with an exclamation point. Phil Hirschkorn, Jury Deliberation Begins in 9/11 Trial, cnn.com, Apr. 24, 2006.

116 For an example of a jury instruction created by a district court, see United States v. Sampson, 335 F. Supp. 2d 166, 189.91 (D. Mass. 2004). For examples of state pattern VIE instructions, see, e.g., Cargle v. State, 909 P.2d 806, 828 (Okla. Crim. App. 1995); Commonwealth v. Means, 773 A.2d 143, 159 (Pa. 2001).

117 Payne, 501 U.S. at 825.

118 Id.; see also id. at 827 ("There is no reason to treat [VIE] dif. ferently than [how] other relevant evidence is treated.").

119 See Wayne A. Logan, Casting New Light on an Old Subject: Death Penalty Abolitionism for a New Millennium, $100 \mathrm{MicH}$. L. REv. 1336, 1342.43 (2002) (discussing various ways in which this distinctiveness has diminished). See also Carol S. Steiker \& Jordan S. Steiker, Sober Second Thoughts: Reflections on Two Decades of Constitutional Regulations of Capital Punishment, 109 HARV. L. REv. 355, 397 (1995) ("close examination of the Court's decisions ... reveals that the procedural safeguards in death cases are not as different as one might expect ... . [The Court often] has relegate[d] capital defendants to the same level of protection as non-capital defendants.").

120 See Booth, 482 U.S. at 516.17 (White, J., dissenting) (criticiz. ing majority's ban of VIE in capital yet not noncapital trials). 